\title{
Improving institutional and service delivery capacity in conflict affected areas: The experience of Honiara City Council, Solomon Islands
}

\section{Commonwealth Journal of Local Governance \\ Issue 6: July 2010 \\ http:/lepress.lib.uts.edu.au/ojs/index.php/cjlg}

\section{Terry Parker ${ }^{1}$}

Regional Adviser (Commonwealth), Alliance of Mayors and Municipal Leaders on HIV/AIDS in Africa

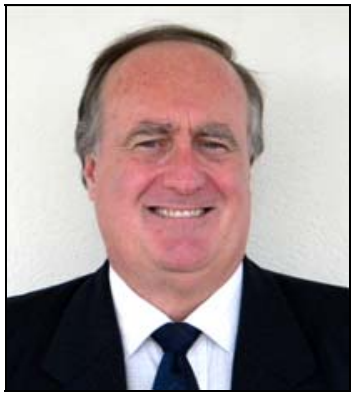

\section{Introduction}

Solomon Islands is a chain of 922 islands in the South Pacific, spread over 1,450kms from Bougainville (Papua New Guinea) in the north to Vanuatu in the south, and covering an area of $27,450 \mathrm{kms}^{2}$. The country is home to some 520,000 people, with 74 different languages and dialects. It is divided into nine provinces, each centred on a main island. Effectively, there are nine different peoples with strong allegiance to family, village and province, but little common national identity upon which to effectively build a state.

Honiara, located on the island of Guadalcanal and surrounded by the province of the same name, is the national capital, seat of government, centre of administration and commerce, and the nation's window to the world. The city has a population of 79,000, including an estimated 20,000 or so inhabiting informal settlements in the urban and peri-urban areas. Honiara has one of the highest urban growth rates in the Pacific region, estimated at 4\% per year ${ }^{2}$. Made up of indigenous peoples from all provinces (Malaitans being particularly numerous), expatriates and a large Chinese community, the city is a

${ }^{1}$ Formerly Regional Adviser, Commonwealth Local Government Forum Pacific Project.

2 Secretariat of the Pacific Community, 2007. 
melting pot of the diverse ethnic groups that are the Solomon Islands. In practical terms, however, Honiara is a somewhat artificial social construct. There is no genuine local identity or ownership of the place; although people may reside in Honiara, and may have for all their lives, their roots remain in their home village or province.

Honiara City Council is the governing local authority ${ }^{3}$ for the capital. The council comprises 20 members (12 elected, 8 appointed) and is mandated to deliver the typical range of standard municipal infrastructure and social services, with added responsibilities for primary health care (including 9 clinics) and education (14 schools). It employs over 400 staff in its service delivery operations.

This paper is based largely on a presentation made by the Lord Mayor of Honiara and the author to a technical seminar entitled Local Government and Basic Service Delivery in Conflict Affected Areas, held jointly by UNDP and UNESCAP in Bangkok, Thailand in June 2009. ${ }^{4}$ It will focus on the complex role and place of the Honiara City Council in improving its institutional legitimacy and service delivery capacity following a period of national instability, and the partnership with the Commonwealth Local Government Forum (CLGF) Pacific Project which has supported the Solomon Islands Government and the council in these endeavours. It will draw the important linkage between delivery of equitable basic services and the potential for prevention of conflict.

\section{The Conflict}

Known locally as 'the tensions', the conflict situation that has most notably impacted on Solomon Islands society began in 1998 when militant youths from the island of Guadalcanal attacked settlements of islanders from other provinces, mainly from the neighbouring island of Malaita, close to Honiara. Issues of land linked with indigenous rights, and the failure of authorities to address articulated concerns, provided the motivation. The conflict has been seen by some analysts as a spill-over from the crisis in Bougainville, given the socio-cultural similarities.

\footnotetext{
3 Although classed as a local government, the City Council operates effectively as a province.

${ }^{4}$ Refer http://www.unescap.org/pdd/calendar/ESCAP_UNDP_governance/index.asp The author gratefully acknowledges the contributions to this paper by Lord Mayor Andrew Mua, an outstanding local leader who inspires faith in the future of local government in the region, along with background material provided by the former City Clerk, Wayne Hart.
} 
The action of the Guadalcanal militants resulted in the displacement of over 30,000 people. The conflict escalated in early 2000 when a resistance group claiming to represent the interests of displaced Malaitans, armed themselves and took control of Honiara. This resulted in a breakdown of law and order, instability and collapse of the institutions of government.

Peace was eventually restored through several initiatives, some more successful than others. The Townsville Peace Accord in October 2000, followed by the intervention of the Regional Assistance Mission to Solomon Islands (RAMSI) in 2003 under the auspices of the Pacific Islands Forum, achieved some degree of restoration of peace and normality. A Local Peace Monitoring Council and International Peace Monitoring Team supported these efforts. A proactive policy of national reconciliation and rebuilding reinforced the peace building initiatives. A constitutional review process and the establishment of a Truth and Reconciliation Commission followed more recently.

The role of women in the peace building initiatives, both during and after the tension warrants special mention. Organised women's groups took a proactive stance against the violence, which plainly was perpetrated by men, and mobilised support for children and other vulnerable groups, particularly during the worst of the conflict. This was an example of where women are not simply victims of conflict situations but can in fact contribute to reducing fragility and strengthening social cohesion.

The fragility of the peace was, however, revealed in April 2006 when riots broke out in Honiara after the election of a new Prime Minister, who was perceived by the rioters to be in the pocket of certain sectoral interests. This resulted in the targeted burning of businesses in the Chinatown district. Again, the root causes of the riots were attributed by a Commission of Inquiry to amongst others, inequitable access to land, failure of government to deliver development to settlements in Honiara and bad governance. ${ }^{5}$ Significantly for this paper, the Commission established a linkage between inadequate service delivery and the more recent conflict.

The 18th April 2006 civil unrest and riot in Honiara took place against a backdrop of infrastructure weakness and non-delivery of the essential government services to the people from all over the country, who by accident or desire, have made Honiara their home. In search of a better prospect in education, health and employment, these people have settled in

\footnotetext{
${ }^{5}$ Report of the Commission of Inquiry into the April 2006 Civil Unrest in Honiara, 2009, p2.
} 
distinctive original provincial or island ethnic settlements in and around Honiara in near squalor conditions because government services were not reaching them.

High hopes and expectations of a better life from the rural areas from where they had migrated into Honiara had not materialised as many cannot find employment. The poor access roads into the settlements, the lack of proper sewerage, water supply and electricity, high costs of school fees, lack of adequate health facilities and the high incidence of drunkenness are some of the daily woes settlement dwellers had to deal with, often with no government support.

It is in the context of this daily hardship that settlement dwellers are highly vulnerable to exploitation and manipulation, and the national elections for a new Solomon Islands Parliament in early April 2006 became the catalyst for them to let out their anger and frustration against the government in particular, and society in general. ${ }^{6}$

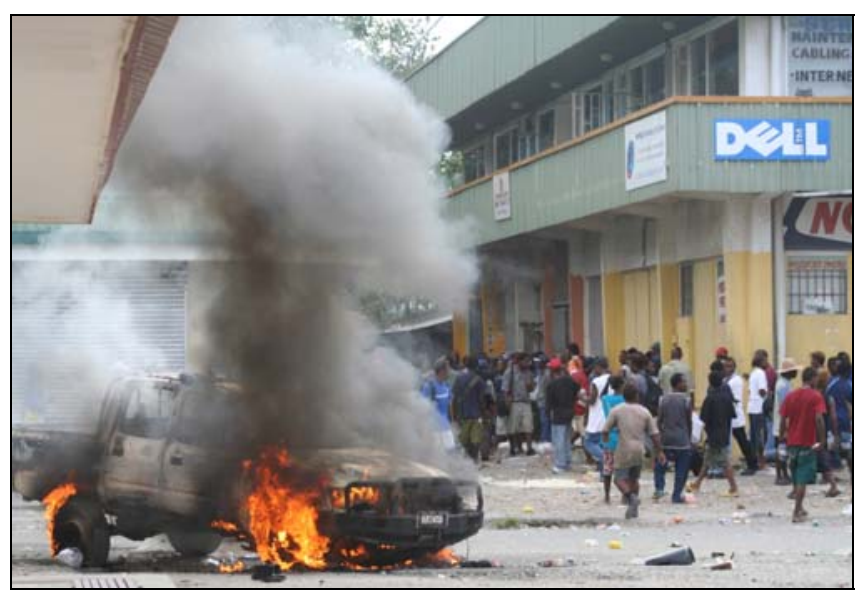

A vehicle set fire in the commercial district of Honiara during the April 2006 riots
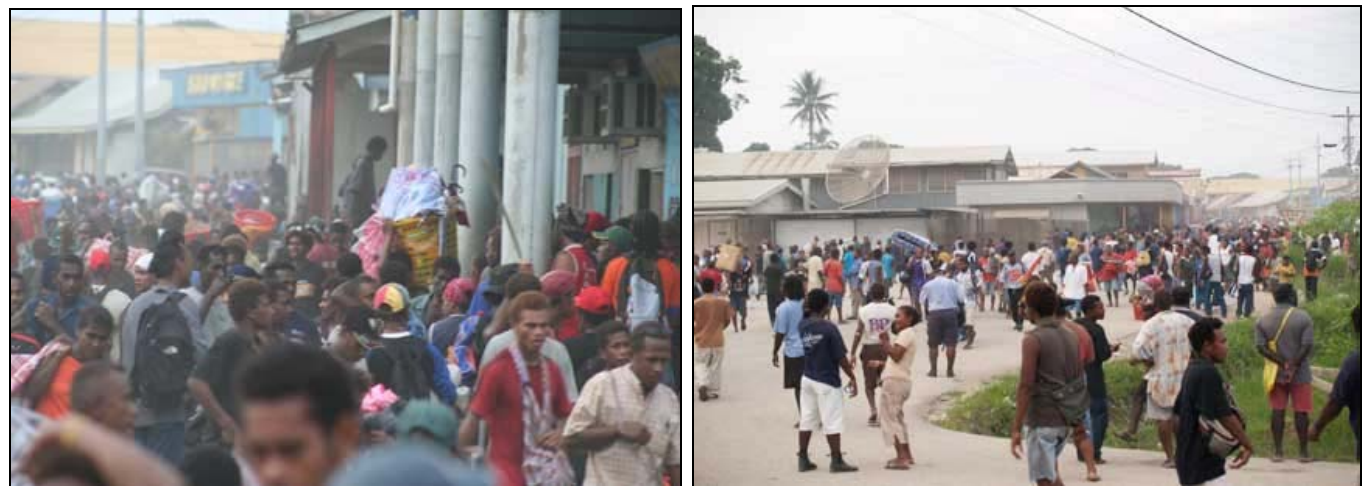

Crowds in the main commercial district of Honiara during the April 2006 riots

${ }^{6}$ ibid p8. 

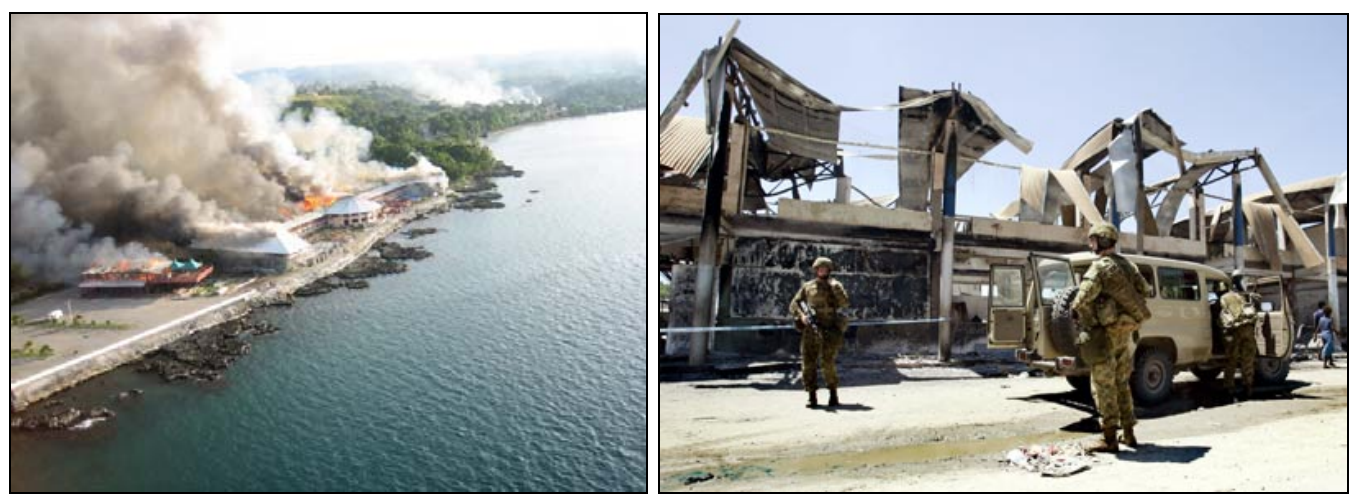

The Pacific Casino Hotel on fire after the April 2006 riots. This hotel was one of the commercial buildings targeted by the rioters. Right, Commercial building in the main street of Honiara after the April riots.

\section{Honiara City Council and the Tensions}

Honiara City Council itself was certainly not immune from breakdown of the institutions of governance as a result of the tensions. The violence and destruction was most intense in Honiara, given its diverse ethnic mix. The results were a disintegrated and divided community; destruction of physical and social infrastructure; openly corrupt practices; political leaders opportunistically capitalising on people’s ignorance for personal gain; huge debts; and a dysfunctional Council, which was dissolved by the responsible Minister in 2004 and replaced by an appointed authority pending fresh elections. Technically the authority had the same powers as the council, but its limited mandate reduced its effectiveness. Thus, after the tensions of the early 2000s the Honiara City Council had lost its institutional integrity, legitimacy and much of its service delivery capacity. The Commission of Inquiry later concluded that "there had been major failings within the Honiara City Council to coordinate, organise and deliver development in the Honiara settlements," ${ }^{7}$ and even went so far as recommending permanent replacement of an elected council with a statutory commission.

A newly elected council had taken the place of the appointed authority in August 2006. This new council faced several challenges, in addition to those attributed to the tensions and the aftermath of the April riots. Issues that impacted on service delivery in such an environment included:

\footnotetext{
7 ibid p43.
} 
- Urban drift and growth in informal and peri-urban settlements, resulting in increased demand for services, revenue gaps, cultural segregation, youth unemployment etc

- Cultural obligations and expectations, particularly the renewed influence of the 'wantok' system, ${ }^{8}$ and the need to maintain neutrality and equity in decision making and operations

- Absence of common national and local identity, a precondition for inclusive community building

- Inadequate revenue relative to high service delivery expectations

- The emerging challenge of the effect of the global economic downturn on Solomon Islands and the likely severe impact on the urban poor and informal settlements.

\section{Honiara City Council Institutional Capacity Building Project}

As early as 2003, in the immediate aftermath of the tensions, the government of the Solomon Islands recognised the need for an operational Honiara City Council as an essential component of the reconciliation and rebuilding process. However, the government also acknowledged that assistance would be needed. A request was subsequently made to the Commonwealth Secretariat for technical assistance to help rebuild the Honiara City Council institutions.

This task was passed to the Commonwealth Local Government Forum (CLGF), as the Designated Commonwealth Organisation for local government, through its Pacific Regional Project based in Suva, Fiji Islands. CLGF Pacific Project works with local government and other stakeholders in the region to strengthen local democracy, institutions and service delivery capacity of sub-national governments in nine Pacific Island Commonwealth countries, including Solomon Islands. This is done through several inter-related projects founded on Commonwealth principles of local democracy and good governance.

The request by the Solomon Islands Government and a subsequent investigation and preparatory process by CLGF and several of its partners, ${ }^{9}$ Honiara City Council and the

\footnotetext{
${ }^{8}$ Literally 'one talk', loosely defined as those speaking the same language or from the same family or clan, and can be expanded to include provincial areas. Essentially a social contract of obligation to assist each other in times of need. The system has been compared to nepotism and favoritism, however can also provide an essential safety net in the absence of other social security options.
} 
Ministry of Home Affairs, resulted in the Honiara City Council Institutional Capacity Building Project. This is a five year (2006 to 2011), broad-based technical partnership aimed at supporting the council and its stakeholders to improve institutional and basic service delivery capacity. It is targeted towards achieving the council's vision of an inclusive and well serviced capital city in order to support sustainable urban development and the maintenance of peace and stability.

The project recognises that the council operates in a changing and complex environment, facing the challenges of increasing urbanisation, and high expectations versus inadequate resources. Priority issues such as informal settlements, urban security and stability underpin the project design which aims to strengthen the council's capacity to respond effectively to these challenges and to deliver adequate local government services.

The goal of the Project is to bring about substantial improvements in quality of life for all citizens of the City of Honiara through sound city management, improved local services, planned urban development and good governance. Key objectives and a wide range of project activities support attainment of this goal, grouped under four themes:

- Strengthened council management capacity and processes

- Improved quality and delivery of essential services

- Coordinated and well-planned urban development

- Good governance and local democracy

Funding, as well as guidance and moral support for the project is provided by the New Zealand Agency for International Development (NZAID), which as a development partner genuinely understands the important role local government can play in social development and nation building. This belief by NZAID, and maintaining faith during challenging times, was a crucial element in rolling out the project. NZAID agreed to fund the project to the extent of some NZ\$5.4 million over the five year period. Support for the project was also provided by the Commonwealth Fund for Technical Cooperation through funding the CLGF Regional Adviser position.

${ }^{9}$ Including UTS Centre for Local Government, Sydney; Local Government New Zealand; Local Government Managers Australia; Papua New Guinea Urban Local level Government Association; Kapiti Coast District Council (New Zealand); Maryborough City Council (now Fraser Coast District Council, Australia); UN Habitat and INGENIUM New Zealand. 
A mix of approaches and activities is being applied to effect the required capacity development. These include direct support for external in-line senior staff appointments, with local counterparts; financial assistance for materials and equipment to enhance service delivery; technical support from the CLGF Pacific Project and partners; technical staff exchanges with New Zealand and Australian councils; and direct technical assistance for specific assignments.

The project is founded on partnerships at several levels, with local government authorities and professional colleagues sharing knowledge and experience. Conflict sensitivity underpins strategic decisions as the project proceeds. It is a complex, complicated and evolving project, having experienced several challenges and setbacks along the way. Even when they are made, gains can be fragile given the operating environment and could be lost or undermined if the factors contributing to progress are reversed. However the risks associated with a project such as this are the very reasons why it is so necessary.

\section{Improving Service Delivery in a Post-Conflict Environment}

In view of the range of challenges inherent in delivering quality local government services to all citizens of Honiara, the council and its project partners understood and accepted the realities and accordingly factored in socio-cultural dimensions, inclusiveness and conflict sensitive strategies into its governance and service delivery policies and practices. In particular the council’s strategy encompassed:

- Genuine recognition of informal and squatter settlements - they are all Solomon Islanders and 'our people', having rights to equal access to services irrespective of ethnicity, socio-economic status, location or political persuasion

- Neutrality in professional operations by accepting expatriates as senior advisers and in-line managers and later choosing to appoint an expatriate as City Clerk/Chief Executive Officer, with local counterparts and succession plans

- A formal and real commitment to openness, transparency, fairness and inclusiveness in decision making and service delivery

- Consultative and representative processes for all citizens - through public consultations and Ward Advisory Committees, participatory community events such as clean up campaigns, community outreach programs etc

- Establishment of a Council of Chiefs for Honiara as a forum to address ethnic issues and potential conflicts, and to recognise and bring on board the influence of traditional leaders as partners in the City Council's initiatives 
- Involving unemployed youth as a valuable source of social capital through community based works projects

- A better trained, led and informed elected body

- Developing a roadmap for the future development of Honiara - the City Vision.

However, this strategic approach required a significant paradigm shift, time, and substantial support to realise the changes sought.

Some noteworthy achievements have resulted so far. The council's own source revenues (principally local taxes, property rates and service charges) have increased more than sixfold, management systems have been enhanced and service delivery capacity improved, particularly in the areas of solid waste management, roading, markets and health clinics. Now that the council has greater capacity to deliver better services and improved governance, working relationships with central government agencies have improved and cooperation as not seen before on key strategic issues such as land, decentralisation, urbanisation, security and conflict prevention is happening. Leadership development programmes have been carried out, with a focus on the complexities of conflict and fragile situations, and local economic development initiatives, focussing on the lower socio-economic groups and the 'parallel' economy, which is more immune from the global economic slowdown, are in place. Community engagement strategies are being implemented and progress, albeit slow, is being made on developing working relationships with the informal settlements which in the past have been openly hostile to the council.

The CLGF project is now in the final stages of the current phase. Dialogue is underway with NZAID and other key stakeholders on the next stage, given that there is an undeniable need for continuation of support to Honiara City Council in the foreseeable future and the project model is beginning to show evidence that with solid input an organisation can be lifted. There is much work still to be done, particularly on the various dimensions of community development.

\section{Lessons Learned}

An external review of the project was carried out in August/September 2009, which concluded: 
The Project was and remains highly relevant to the needs of Honiara, to development strategies for the Solomon Islands, and to related programs of donors including NZAID, AusAID and RAMSI. It is also contributing significantly to addressing key cross-cutting issues.

After a slow start, over the past year the Project has made excellent progress. This reflects in particular the work of the new Mayor and City Clerk. HCC has made great strides, including repaying debts and greatly enhancing service delivery. The dramatic increase in its own-source revenues is an outstanding Project achievement, and is now being augmented by the council's own efforts. Overall, it is fair to say that directly and indirectly the Project has restored HCC’s institutional legitimacy and integrity, and has demonstrated that effective city government is achievable, albeit that much remains to be done. ${ }^{10}$

This review, together with a recent project re-design exercise undertaken by NZAID, will inform the decision making processes in respect to future support to Honiara City Council. As stated earlier, the project is broad based, covering a variety of policy, strategic, implementation and review phases. At its inception, the project did not specifically target conflict prevention and peace building, but as it progressed, the importance of Honiara City Council and service delivery to community reconciliation, consensus building and nation rebuilding became increasingly apparent. It is clearly a cross-cutting issue that required focus.

It is realistically too early to assess if the initiatives of the council and the project have resulted in any specific benefits in terms of conflict prevention. In particular there has not been any monitoring as yet of the response of householders to improved services, particularly in the 'hot spots'. However the external review noted that there is widespread recognition of the importance of providing basic services as a way to reduce the likelihood of conflict, ${ }^{11}$ and several key messages that can be drawn from Honiara City Council's and CLGF's efforts thus far.

- There is a clear link between effective and equitable municipal service delivery, physical and social, particularly to informal settlements, and conflict prevention. The understanding and acceptance of the lack of a common national and local 'identity' in Solomon Islands makes this variable even more important. In particular, mainstreaming conflict prevention strategies into service delivery plans is critical. In this context, perceptions of the diverse 'communities' in Honiara as

10 Sansom, G. and Whitaker, K. 2009 Honiara City Council Institutional Capacity Building Project Mid Term Review, Commonwealth Local Government Forum Pacific Project and New Zealand Agency for International Development, p3.

11 ibid p17. 
to the parity of service delivery are equally important as the actual delivery itself. Accordingly, it is incumbent on the council to ensure not only that services are in fact being fairly distributed across the city, but also that the community is made aware of this equitable delivery. The same can apply to regulatory responsibilities.

- It was important to achieve visible 'quick wins' at the beginning of the development process to strengthen ties among stakeholders and build support for the council's rebuilding initiatives. This particularly applied to communities previously excluded from equitable service provision. The legitimacy of the institution is strengthened through evidence of actual delivery of services. Citizens once they are better empowered to exercise their rights, recognise and appreciate action, not just rhetoric.

- Sound financial management, governance and accountability are critical. For example, the substantial increase in property rates revenue has afforded additional capacity for service delivery and inclusiveness. Prudent application of the additional resources has resulted in significant improvements.

- Delays were experienced when the complexity and depth of the problems at Honiara City Council were properly revealed after the project funded personnel began work - the 'unknown unknowns' of development work. The post-conflict operating environment did not assist. This meant that significantly more time was needed to effect any meaningful change than was first anticipated.

- Community empowerment through wide-ranging consultation and engagement of both formal and informal settlements, youth and women, traditional and church leaders is critical for 'ownership', sustainability, community cohesion and building the legitimacy of the City Council.

- Honiara as the national capital needs to be better embraced by the Solomon Islands government, with urban management and local governance reflected higher on the policy agenda given the realities and impacts of urban growth.

- Stability of government and administration at both national and local level is conductive to quality service delivery. Political instability experienced at national level in 2006/07 and at local level up until the tenure of the current Lord Mayor, presented a major diversion to effective governance at all levels. Similarly, several changes in Honiara City Clerks since the intervention began had a 
destabilising effect until the expatriate appointed in 2008 came to grips with the position.

- Working in partnership with community, national government, civil society and development agencies, and delivering through those partnerships will help win back credibility and institutional respect.

- It is not easy and there is a long way to go, but much can be achieved with political will and commitment.

CLGF has also learned much in delivering its support project. Working in conflict affected environments reveals a special role for a development partner. Sustainability of gains in such an environment can be fragile. The dilemma often faced is in adapting accepted social development principles, such as local ownership of the process, in a dysfunctional environment. In such situations there is a tendency for a development partner to apply a leveraging style in order to get the job done. In the case of this project, the concept of 'power sharing' was agreed by all partners, where project direction and day to day implementation decisions are made collaboratively within the framework of the intervention, and based on collective responsibility. This has proven to work well, with growing engagement by project partners and a gradually increasing rate of progress.

During this process the question as to the most appropriate governance system for Honiara has been raised. The dynamics of the city and the conflict experiences have led to some reflection as to whether the existing 'western style' local government structure in Honiara is the way to go, or whether a more indigenous system that may take account of the socio-cultural construct of the city, particularly informality and ethnicity, would be better. The current national constitutional review is actively examining this issue of the place of Honiara, particularly in the context of a federal system that is being considered. However, given the volatility of the Solomon Islands political system and for the purposes of this piece, it may be better to reserve this debate for another day.

\section{Conclusion}

Across the Commonwealth, the role of effective local government in helping to strengthen the state as a whole is being more widely recognised. Local government provides many of the basic services that are essential to reducing poverty and improving the livelihoods and quality of life of citizens. The Honiara City Council scenario affords 
evidence of the importance of providing equitable basic services to the prevention of conflict. In order to improve institutional and service delivery capacity at local level in conflict affected areas local governments need to factor socio-cultural and conflict sensitive strategies into governance and service delivery policies and practices. Local governments are well placed to promote community reconciliation, and as such proactive community engagement post conflict is critical. The key role of women it this process should not be ignored.

The importance of strong local leadership underpins all these efforts. Helping build and maintain good local government leaders should be a focus of any technical support program. However, at the end of the day, the individuals involved need to have the right personal motivation - as the participants in the recent UNDP/UNESCAP Technical Seminar noted, there are many examples in conflict affected areas where the heroes of today can be the tyrants of tomorrow.

Although some meaningful progress has been made by the City Council with the support of the CLGF project, in implementing the agreed strategic approach, there is some way to go and the overall situation in the city remains fluid. The circumstances are best summed up by the 2009 review that concluded:

....although the general situation in the Solomon Islands is currently calm, many of the underlying factors that brought about the 'tensions' and the more recent civil unrest in Chinatown are still present. For example, squatter communities are still growing as more people move into Honiara City. This calls for not only ongoing improvements in the City Council's own performance - and people's perceptions of that performance - but also a closer and more productive working relationship with Solomon Islands Government agencies and Guadalcanal Province on the underlying strategic issues. ${ }^{12}$

\section{References}

Commonwealth Local Government Forum Pacific Project - Honiara City Council Institutional Capacity Building Project Annual Reports 2008 and 2009. Commonwealth Local Government Forum.

Commission of Inquiry into the April 2006 Civil Unrest in Honiara Report. Honiara 2009.

Honiara City Council and Commonwealth Local Government Forum Pacific Project. Program Design Document. Honiara City Council Capacity Building Project, 2006 to 2011.

McGovern, Kieren and Bernard Choulai 2005. 'Case Study of Solomon Islands Peace and Conflictrelated Development Analysis', United Nations Development Program Human Development Report Office Occasional Paper 2005/33.

<http://hdr.undp.org/en/reports/global/hdr2005/papers/hdr2005_mcgovern_and_choulai_33.pdf >

\footnotetext{
12 ibid p14.
} 
Sansom, G. and Whitaker, K. 2009, 'Honiara City Council Institutional Capacity Building Project Mid Term Review’, Commonwealth Local Government Forum Pacific Project and New Zealand Agency for International Development.

United Nations Development Program and United Nations Economic and Social Commission for Asia and the Pacific. Local Governance and Basic Services Delivery in Conflict Affect Areas: Report of Technical Seminar held in Bangkok, Thailand June 2009. 